\title{
Reflections on Qualitative and Mixed Methods Researches
}

\author{
Ana M. Pinto-Llorente \\ Faculty of Education \\ University of Salamanca \\ 37008 Salamanca, Spain \\ ampintoll@usal.es
}

\author{
M. Cruz Sánchez-Gómez \\ Faculty of Education \\ University of Salamanca \\ 37008 Salamanca, Spain \\ mcsago@usal.es
}

\author{
António Pedro Costa \\ Education and psychology Department \\ University of Aveiro \\ 3810-193 Aveiro, Portugal \\ apcosta@ua.pt
}

\begin{abstract}
This is the second edition of the track Implementation of Qualitative and Mixed Methods Researches in the International Conference on Technological Ecosystems for Enhancing Multiculturality (TEEM). The aims of the track are to present the most relevant qualitative studies and those that integrate qualitative and quantitative approaches in research designs, and to provide a space for reflexion.
\end{abstract}

\section{CCS CONCEPTS}

- Applied computing $\rightarrow$ Education $\rightarrow$ Learning management system engineering • Social and professional topics $\rightarrow$ Professional topics $\rightarrow$ Computing education $\rightarrow$ Adult education

\section{KEYWORDS}

Mixed methods research, quantitative research, qualitative research, triangulation, integration.

\section{ACM Reference format:}

A. M. Pinto-Llorente, M. Cruz Sánchez-Gómez and A. P. Dias Da Costa. 2019. Reflections on Qualitative and Mixed Methods Researches. In Proceedings of the Seventh International Conference on Technological Ecosystems for Enhancing Multiculturality (TEEM 2019) (León, Spain, October 16-18, 2019), ACM, New York, NY, USA, 3 page. https://doi.org/10.1145/3362789.3362941/

\section{Introduction}

The integration of quantitative and qualitative approaches in research design pretends to reconcile both paradigms and overcome the traditional confrontation that has existed over centuries [1,2]. That integration can be seen in the works Permission to make digital or hard copies of all or part of this work for personal or classroom use is granted without fee provided that copies are not made or distributed for profit or commercial advantage and that copies bear this notice and the full citation on the first page. Copyrights for components of this work owned by others than the author(s) must be honored. Abstracting with credit is permitted. To copy otherwise, or republish, to post on servers or to redistribute to lists, requires prior specific permission and/or a fee. Request permissions from Permissions@acm.org.

TEEM'19, October 16-18, 2019, León, Spain

(C) 2019 Copyright is held by the owner/author(s). Publication rights licensed to ACM.

ACM ISBN 978-1-4503-7191-9/19/10...\$15.00

https://doi.org/10.1145/3362789.3362941/ developed by different mathematicians and social researchers a few years ago which were based on two main premises [3]. On one hand, they pointed out how quantitative and qualitative methods needed each other in order not to lose their meaning. It was emphasized how the meaning was diluted without the measure and the measure without meaning was only a mere number. On the other hand, social science researchers attempted to foster the development of adequate mathematical patterns of analysis since they normally work with qualitative data. They clearly tried to define the general epistemological formulations on which qualitative methods are based in more precise and current methodological proposals since nowadays there is a tendency in the use a mixed methods research [2].

It is possible to point out different levels in which it could be studied the relationship between quantitative and qualitative researches.

Flick $[4,5]$ points out, on one hand, studies in which there is a prevalence of the quantitative data over the qualitative one, or, on the other hand, investigations in which the qualitative data predominate over the quantitative ones. Besides, he refers to the combination of both quantitative and qualitative data that can pretend to transform qualitative data into quantitative ones or vice versa.

Flick $[4,5]$ also emphasizes the possibility of the combination of quantitative and qualitative methods in research design. In that case, he refers to three different ways to carry out that integration.

First of all, the author refers to sequencing that implies that qualitative and quantitative researches are placed in different stages of the research process.

Secondly, he talks about triangulation of qualitative and quantitative research. That means the combination of several qualitative methods as well as the combination of qualitative and quantitative methods.

These two first methodological perspectives, as the author points out, complement each other in the study of an issue and compensate the weak points of each single method. However, the different methods continue being autonomous, operating side by side, and their meeting point is the problem under study. None of them is consider better or preliminary.

Finally, the author refers to the integration of qualitative and quantitative research that means the continuous collection of both kinds of data.

From a methodological point of view the $21^{\text {st }}$ century starts with a third orientation called pragmatic approach and advocates 
hybrid and mixed methods. It is possible to emphasize different relevant event along the Twentieth-First Century that have contribute to the growth of mixed methods researches.

In 2003 it was published the special issue of the British Educational Research Journal about educational research in which four of the papers presents a research using mixed methods.

In 2007 it was published the first number of the Journal of Mixed Methods Research. A international publication that focuses on empirical, methodological, and theoretical articles about mixed methods research across the social, behavioural, health, and human sciences.

Finally from 2008 to 2015 relevant researchers as Cámeron \& Quinn [6], Charmaz [7], Creswell y Plano Clark [8], Hernández, Fernández \& Baptista [9], Morse [10], Morse \& Niehaus [11] and Tashakkori \& Teddlie $[12,13]$ published significant works.

We also highlight the work of Anguera [14] that states that the combination of qualitative and quantitative methodology enhances the mutual invigoration of the two types of methods, and facilitates the triangulation through operations.

Delgado [15] also emphasizes this idea and considers that it is a combination of the creativity and plasticity of the qualitative method and the formal rigour of the quantitative one. It is a flexible combination of quantitative and qualitative components in stages of the study.

In the following lines, we want to allude to the different reasons that explain the development of mixed methods researches $[9,16,17,18,19,20,21,22,23,24,25,26,27]$.

The first reason refers to the triangulation of quantitative and qualitative data, contrasting these data to get greater external and internal validity of the research. The second one has to do with complementation since it contributes to the understanding of the results of one of the methods based on the results obtained in the other. The third reason concerns compensation, so the weaknesses of each method are counteracted and their strengths are reinforced. The fourth reason, it is related to clarity since it is possible to show elements that cannot be detected by a single method. On the other hand, there is diversity, providing different perspectives of the issue. It also favour the initiation because of the discovery of contradictions or new frames of reference as well as the modification of the original approach and the results of one of the methods with questions and results of the other. Another reason is the amplitude, a holistic vision that permits having a more comprehensive and complete vision of the issue. Moreover, there is an expansion since one of the methods extends the information, which was obtained by the other. Besides, these experts emphasize the multiplicity of answers for a greater number of questions that are replied deeply as well as the development since the results of one method support the other's processes. It also reinforcing the credibility of the results of both methods as well as the illustration of different ways the results obtained as well as the argumentation, consolidating the reasoning from the collection and analysis of the data by both methods. Finally, there is a decrease of the uncertainty of the unexpected results since one method or the other helps to explain them.

\section{Track organization}

This section describes in further detail the contributions accepted to participate in the current Conference track Implementation of Qualitative and Mixed Methods Researches.

\subsection{Mixed methods and visual representation of data with CAQDAS: empirical study}

The first paper of the track is a mixed methods research carried out by Sonia Verdugo-Castro, $\mathrm{M}^{\mathrm{a}}$ Cruz Sánchez Gómez, Alicia García-Holgado and Antonio Pedro Costa [28] that tries to identify the socio-labour actions implemented by third sector entities with people at risk and socially excluded, among them it is emphasized the high presence of women who were victims of gender violence. Moreover, most of the people were unemployed. The research specifically focused on the social intervention offered by those associations to develop prevention and intervention on social vulnerability.

A total of nine entities of the third sector of Valladolid participated in the research. Employees of those nine entities were interviewed and composed the sample of the study.

Regarding the results, the tasks that were most developed by the different entities were training in socio-labour skills and motivation, pre-labour training, individualised itineraries, insertion and socio-labour reintegration workshops; followed by socio-labour intermediation, orientation towards selfemployment and training in digital skills.

They also emphasized how not all the entities had the enough spatial-temporal as well as professional resources to develop the work of socio-labour orientation. As the researchers concluded, that implied that the attention of each entity was different.

\subsection{Gender gap in the Digital Society: a qualitative analysis of the international conversation in the WYRED project}

Nadia Sánchez Santos, Alicia García-Holgado and $M^{a}$ Cruz Sánchez-Gómez [29] present a research developed in the context of the WYRED project whose design was based on the phenomenological method of exploratory nature. The WYRED project is a project funded by the European Union and coordinated by the Research Group in InterAction and eLearning (GRIAL) of the University of Salamanca. That project tries to allow young people from different European countries to communicate and give their opinions about the issues that they are interests in. A technological ecosystem was developed to achieve that objective.

The current research focused on the data extracted from the conversations carried out about gender stereotypes and equality on the Internet, coding a total of 275 comments published between February 25 and March 7, 2019. 
The conclusions of the research indicated that one of the main concerns of young people was equality between women and men. It was also emphasized that there were good possibilities for improvement. Education and training in values play a relevant role in terms of equality. Moreover, it was pointed out the necessity of the awareness of the society in terms of equality. All that it would guarantee the same academic and work possibilities for future generations as well as the same rights irrespective of their gender.

\subsection{Mixed methods: Lessons learned from five cases of doctoral theses}

Finally, Jaime Ricardo Valenzuela-González [30] has carried out a research whose aim was to present a reflection on the lessons learned that the researcher synthesizes from his work as an adviser of five doctoral theses using mixed methods.

To this end the researcher opted for a phenomenological approach, using a multiple case studies. Specifically, in this study, he analysed a total of five cases to study and describe the use of mixed methods researches carried out by students of the Doctoral program in Educational Innovation of Tecnológico de Monterrey (Mexico).

The results obtained clearly point out five relevant points regarding mixed methods researches that refer to methodological references, philosophical foundations, methodological variations, precision of terms, and learners' training.

\section{REFERENCES}

[1] F. Conde. 1995. Las perspectivas metodológicas cualitativa y cuantitativa en el context de la historia de las ciencias. In Métodos y técnicas cualitativas de investigación en ciencias sociales, J. M. Delgado and J. Gutiérrez Fernández, Coords. Síntesis. Madrid, 53-68.

[2] M. C. Sánchez-Gómez. 2015. La dicotomía cualitativo-cuantitativo: posibilidades de integración y diseños mixtos. Campo Abierto. Revista De Educación, 1, 1, 11-30

[3] E. Bericat. 1998. La integración de los métodos cuantitativo y cualitativo en la investigación social. Ariel. Barcelona.

[4] U. Flick. 2004. Introducción a la Investigación Cualitativa. Morata Madrid.

[5] U. Flick. 2014. La gestión de la calidad en la investigación cualitativa. Morata. Madrid.

[6] K. S. Cameron and R. E. Quinn. 2011. Diagnosing and changing organizational Culture: Based on the competing values framework. Jossey Bass. Reading, MA

[7] K. Charmaz. 2013. Constructing grounded theory. SAGE. Thousand Oaks, CA.

[8] J. W. Creswell and V. L. Plano-Clark. 2006. Designing and conducting mixed methods research. SAGE. Thousand Oaks, CA.

[9] R. Hernández, C. Fernández and M. P. Baptista. 2014. Metodología de la investigación. McGraw Hill, México.

[10] J. M. Morse. 2012. Qualitative health research: Creating a new discipline. Left Coast Press. Walnut Creek, CA.

[11] J. M. Morse and L. Niehaus. 2010. Mixed method design: Principles and procedures. Left Coast Press. Walnut Creek, CA.
[12] A. Tashakkori and C. Teddlie. 2003. The past and future of mixed methods research: From data triangulation to mixed model designs. In Handbook on mixed methods in the behavioral and social sciences, A. Tashakkori and C. Teddlie, Eds. SAGE. Thousand Oaks, CA, 671-702.

[13] A. Tashakkori and C. Teddlie. 2008. Introduction to mixed method and mixed model studies in the social and behavioral sciences. In The mixed methods reader, J. W. Creswell and V. L. Plano-Clark, Eds. SAGE. Thousand Oaks, CA, 7-26.

[14] M. T. Anguera. 2008. Metodologías cualitativas: características, procesos y aplicaciones. In Metodología en la investigación sobre discapacidad. Introducción al uso de las ecuaciones estructurales, M. A. Verdugo et al., Coords. Publicaciones INICO, Salamanca, 141-155.

[15] C. Delgado. 2014. Viajando a Ítaca por los mares cuantitativos, manual de ruta para investigar en grado y en postgrado. Amarú, Salamanca.

[16] A. Bryman. S. Becker and J. Sempik. 2008. Quality criteria for quantitative, qualitative and mixed methods research: A view from social policy. International Journal Social Research Methodology, 11, 4, 261-276. DOI http://dx.doi.org/10.1080/13645570701401644.

[17] J. C. Greene. 2008. Is Mixed Methods Social Inquiry a Distinctive Methodology? Journal of Mixed Methods Research, 2, 1, 7-22.

[18] A. Tashakkori and C. Teddlie. 2008. Quality of inferences in mixed methods research: Calling for an integrative framework. In Advances in mixed methods research, M. M. Bergman Ed. SAGE. Thousand Oaks, CA, 1-7.

[19] R. Hernández Sampieri and C. P. Mendoza Torre. 2008. El matrimonio cuantitativo cualitativo: el paradigma mixto. In Proceedings of the $6^{\circ}$ Congreso de Investigación en Sexología (Instituto Mexicano de Sexología, A C. y Universidad Juárez Autónoma de Tabasco, Villahermosa, Tabasco, México, 2008), J. L. Âlvarez Gayou Ed.

[20] B. Johnson and L. Christensen. 2008. Educational Research. Quantitative, Qualitative, and Mixed Approaches. Sage. Thousand Oaks, California.

[21] B. Johnson and A. Onwuegbuzie. 2004. Mixed methods research: A research paradigm whose time has come. Educational Researcher, 33, 7, 14-26.

[22] B. Johnson, A. Onwuegbuzie and L. Turner. 2007. Toward a definition of Mixed Methods research. Journal of Mixed Methods Research, 1, 2, 112-133.

[23] H. L. O'Brien and M. Lebow. 2013. Mixed-methods approach to measurin user experience in online news interactions. Journal of the American Society for Information Science and Technology, 64, 8, 1543-1556.

[24] A. Tashakkori and C. Teddlie. 2010. Handbook of Mixed Methods in Social \& Behavioral Research. Sage Publications, Inc. Thousand Oaks, California.

[25] J. W. Creswell and V. L. Plano Clark. 2018. Designing and Conducting Mixed Methods Research. SAGE. Los Angeles, CA.

[26] P. Bazeley. 2018. Integrating Analyses in Mixed Methods Research. SAGE. Los Angeles, CA.

[27] E. G. Creamer. 2017. An Introduction to Fully Integrated Mixed Methods Research. SAGE. Los Angeles, CA.

[28] S. Verdugo-Castro, M. C. Sánchez Gómez, A. García-Holgado and A. P. Costa. 2019. Mixed methods and visual representation of data with CAQDAS: empirical study. In Proceedings of the 7th International Conference on Technological Ecosystems for Enhancing Multiculturality (TEEM 2019) (León, Spain, October 16-18, 2019), F. J. García-Peñalvo Ed. ACM, New York, NY, USA.

[29] N. Sánchez Santos, A. García-Holgado and M. C. Sánchez-Gómez. 2019 Gender gap in the Digital Society: a qualitative analysis of the international conversation in the WYRED project. In Proceedings of the 7th International Conference on Technological Ecosystems for Enhancing Multiculturality (TEEM 2019) (León, Spain, October 16-18, 2019), F. J. García-Peñalvo Ed. ACM, New York, NY, USA.

[30] J. R. Valenzuela-González. 2019. Mixed methods: Lessons learned from five cases of doctoral theses. In Proceedings of the 7th International Conference on Technological Ecosystems for Enhancing Multiculturality (TEEM 2019) (León, Spain, October 16-18, 2019), F. J. García-Peñalvo Ed. ACM, New York, NY, USA. 